\title{
General Aspects Regarding Cybercrime Phenomenon
}

\author{
Alexandru SISERMAN \\ University Politehnica of Bucharest, Romania \\ asiserman@yahoo.com
}

\begin{abstract}
Governments, the military and the world economy cannot operate without using a computer. Computers that traded this huge increase of information they communicate through Internet or numerous other military and financial networks. Being an important good, the information must be protected and is useful as long as it remains valid, unaltered and true. Cybercrime is a new category of crime formed in late XX and beginning of XXI which brings violations of law both towards individuals and businesses worldwide, as well as towards the state, causing loss of billions American dollars annually.
\end{abstract}

Keywords: internet, cybercrimes, computer

\section{References}

[1]. Data Protection Working Party (2002), Working document on determining the international application of EU data protection law to personal data processing on the Internet by non-EU based web sites, 5035/01/EN/Final WP 56, Brussels, 30.04.2002.

[2]. Council of Europe (2001), Convention on Cybercrime, Budapest, 23.11.2001.

[3]. De Busser, E. (2012), "The Adequacy of an EU-US Partnership", in S. Gutwirth et al. (eds.), European Data Protection: In Good Health, Dordrecht/Heidelberg/London/ NewYork: Springer, 2012, pp. 203-232.

[4]. De Hert, P. and B. de Schutter (2008), "International Transfers of Data in the Field of JHA: The Lessons of EUROPOL, PRN and Swift", in B. Martenczuk and S. van Thiel (eds.), Justice, Liberty, Security: New Challenges for EU External Relations, Brussels:VUBPress, pp. 303-340.

[5]. European Commission (2001(b)), Commission Communication on Network and Information Security: Proposal for a European Policy Approach, COM(2001) 298 final, Brussels, 6.6.2001.

[6]. European Network and Information Security Agency (ENISA) (2009(b)), Cloud Computing Information Assurance Framework, Heraklion, November 2009.

[7]. EUROPOL, EUROPOL Information Management: Products and Services, The Hague, 2510-271, 2010.

[8]. Hon, W.K., C. Millard and I. Walden (2014), “The Problem of 'Personal Data' in CloudComputing.

[9]. Ruiter, J. and W. Martijn, "Privacy Regulations for Cloud Computing: Compliance and Implementation in Theory and Practice".

[10]. Sartor, G. (2012), "Providers' Liabilities in the New EU Data Protection Regulation: A Threat to Internet Freedoms", EUI Working Papers, Law, No. 24.

[11]. Strange, S. (1992) "States, Firms and Diplomacy", International Affairs, 68. 